\title{
TRUSTEE'S INSURANCE PROTECTION AGAINST SURCHARGE FOR INVESTMENT LOSSES
}

\author{
S. A. Coykendale, JR.*
}

It must be apparent to all that the conduct of a fiduciary business involves the necessity of accepting the dictates of business and economic trends, not to mention the changing status of the law. It was at one time generally felt that waivers and disclaimers of liability would relieve fiduciaries of all liability except for gross negligence and bad faith. This, however, is no longer the rule of conduct. The trend is for both the statutes and the cases to ignore the existence of exculpatory clauses and to hold corporate fiduciaries strictly accountable for errors both of fact and of law and to impose upon them as a class a stricter rule of responsibility than upon individuals acting in the same capacities. The very fact that different standards of conduct may be expected of fiduciaries in different circumstances and under varying rules of law makes the nature and the extent of their liabilities at all times very uncertain. Indeed, these may be said to be impossible of ascertainment until their acts have been judicially reviewed in the light of circumstances existing at the time the acts were committed. Even though upheld in their conduct fiduciaries may not always be able to charge their legal expenses to the estate but may have to absorb them in their own expense accounts.

Where modern business is confronted with serious contingent liabilities, such as those with which the corporate fiduciary business is confronted in an ever increasing degree, the natural impulse is to look to insurance as a means of protection. Accordingly, it is pertinent at this time to raise the question whether corporate fiduciaries in their capacities as administrators, executors, trustees under wills or personal trust agreements, committees for incompetents, guardians and in their various agency capacities, should seek to protect themselves by way of insurance against surcharge or other claims. 'This is one of the questions for individual banks and trust companies to decide for themselves, and if their decision is in the affirmative to direct their efforts toward making such protection more generally available than at present.

Before discussing the present status of such insurance for trustees and its availability to corporate fiduciaries in particular, perhaps it would be well to endeavor to outline some of the problems to be met by insurance.

\section{The Bases of Surcharge LiabiLity}

Corporate fiduciaries throughout the country have had in recent years the unpleasant experience of having to deal with surcharge claims and will as time goes on

- B.S., I912, New York University; special studies, New York University School of Commerce and Fordham University Law School. Vice-President, S. A. Coykendall \& Co., New York. Contributor to various business publications. 
find themselves faced with more claims for alleged breach of trust in the performance of their obligations as fiduciaries. They may also have to answer charges of negligence in the performance of mere agency functions as variously conducted. Claims made against fiduciaries in their various fiduciary capacities constitute what are generally known as surcharge claims and indicate that the trustee has been or will be charged in an accounting before a surrogate's court or in an orphan's court for failure to perform its duties with the skill, prudence and diligence required by the statutes or the common law in the jurisdiction in which the fiduciary conducts its business. The claimant or claimants may charge breach of trust

(I) in retaining non-legals, unproductive investments, or speculative property in an executor's or trustee's account; or in failing to sell securities in time to avoid tax penalties;

(2) in purchasing for a trustee's account, with or without the consent and approval of beneficiaries, investments of a class not permitted by the will or trust deed or by the statutes and cases;

(3) in failing to properly diversify investments;

(4) in failing to correctly apportion or to make any apportionment at all of stock dividends or of arrears of dividends or interest unpaid at the time of sale;

(5) in failing to correctly apportion the profit or loss resulting from the sale of foreclosed real estate, or overpaying life-tenants any income in excess of carrying charges while the property is in foreclosure;

(6) in making overpayments to beneficiaries in any manner;

(7) in loaning money on mortgages in excess of the legal limits or on security which turns out to be other than a first mortgage on improved property;

(8) in overlooking the existence of statutes affecting the conduct of fiduciaries in particular circumstances;

(9) in failing to seek instructions from the courts when, although veto power may actually rest in the hands of a co-trustee or other person, it constitutes gross negligence for the trustee not to act; or

(Io) in exceeding the authority given to the fiduciary through improper interpretation of the will or trust deed.

The foregoing are only some of the likely allegations to be brought by the claimants and do not by any means exhaust the list of possible allegations involving surcharge claims. As a matter of fact, the claimants may even allege "fraud" under the theory of tort liability for failure to fulfill the representations which the fiduciary in its advertising may have held out with respect to any particular skill or special knowledge it may have claimed to possess.

\section{Present Status of Insurance Against Surcharge Liabidities}

Insurance policies as such against surcharge liabilities have not heretofore been made available to corporate fiduciaries. Aside from the lack of any previous actuarial or statistical experience, which alone constitutes an almost insurmountable difficulty from the standpoint of any third party liability insurance business as now conducted 
in this country, there is at present no specific authority under which domestic insurance companies can if they are so disposed undertake this new form of insurance. It is a strange inconsistency but it is nevertheless a fact that, even though the willingness to undertake the business may somewhere exist, yet the specific authority is lacking to permit insurance companies to underwrite the insurance of surcharge liabilities even with the safeguards of the most careful selection of business and the use of "deductibles" as a discouragement to careless practices based upon the existence of insurance. The defect in existing laws may sooner or later be cured by a revision of the insurance laws in the various states whereby casualty and bonding companies may be permitted to underwrite third party liability insurance not only against injuries to persons and damage to property as at present but against civil damage claims of all kinds, including of course claims of the kind under discussion. Until such time, however, as specified powers are given, no domestic companies can undertake the insurance of surcharge liability claims without at least raising serious questions of ultra vires. Nevertheless the trend continues in the direction of holding corporate fiduciaries to a stricter rule of responsibility and liability than heretofore, and the means should be made available at least to experienced and well-managed corporate fiduciaries by which they can, if they wish, protect their stockholders and depositors against loss by the purchase of insurance analogous in form to the insurance now generally carried by accountants and for many years carried by English firms of solicitors. Until insurance of this sort is made available generally, the only protection obtainable is in the form of service and indemnity contracts which are available only to a very limited number of corporate fiduciaries.

\section{Scope of Proposed Insurance Contracts}

The underwriting of surcharge liability insurance must of necessity be surrounded with adequate safeguards not only to prevent the abuse of the fiduciary relationship through undue reliance upon the existence of the insurance but also to avoid cutting off the insurance market altogether through the occurrence of the abnormally high losses which would otherwise inevitably result.

Insurance should in any case take the form of errors and omissions insurancenot the form of an ordinary third party liability insurance policy in which the insurers agree to take over the defense and pay the judgment or settle the claim regardless of any wanton or reckless conduct on the part of the insured. In this case the insurance must of necessity exclude reckless conduct or at least make it impossible for.any fiduciary carrying the insurance to proceed without thought of the consequences merely because protected by insurance. Nevertheless, it must protect the fiduciary who in good faith unwittingly incurs a claim involving a breach of trust. The test of the fiduciary's ability to recover should be: Does the act complained of by, the claimants or self-discovered by the fiduciary constitute a breach of trust committed through the failure of the human equation, or through mistake of fact or law, or does it result from a conscious and deliberate act or omission to act known in advance to constitute a breach of trust according to the will or trust deed and the 
statutes and the finally adjudicated cases pertaining thereto? There should be no question of the right to recover should the act or omission to act constitute an unconscious or inadvertent act as distinguished from a conscious or deliberate act as aforesaid.

While there may be some border line cases in which it may be difficult to distinguish between the two, there should not be much difficulty on this score provided good faith is shown in the fiduciary's dealings with its insurers. The record of the testimony before the referee in the surrogate's court having jurisdiction may clearly show that the act or acts complained of, even though constituting a breech of trust ${ }^{\circ}$ toward the one class or the other making the exceptions, were committed in the exercise of the defendant's sound judgment either without knowledge of the limitations imposed by the will or trust deed and the statutes and cases pertaining thereto, or through an unintentionally wrong interpretation of these documents, or perhaps through the doubtful status of the law as laid down by the courts. Otherwise the proofs as in any other claim for recovery under an insurance contract must be based upon the statements or affidavits of those directly concerned with the act or acts involved in the claim. If, upon the submission of satisfactory statements and after reasonable investigation, it appears that the act or acts were "negligent acts, errors or omissions" and not deliberate and conscious acts committed with full knowledge of the limitations imposed, then the claim should be recoverable without further necessity for submitting proofs of loss.

In no case, however, can the insurance operate in the ordinary manner of third party liability insurance policies wherein the insurers take over the defense and have complete control over the litigating policy to be followed. Instead, that control, subject to reasonable restrictions upon the right to incur expenses or to make settlements without the authority of the insurers, should be left strictly in the hands of the fiduciary to employ its own counsel and to determine its own course of action in the light of circumstances as it deems best for all concerned rather than as the insurers deem best for themselves alone. This does not mean putting the insurers in the hands of their insureds with complete power to bind them to a course of action without the right to be heard, but means merely that the initiative should be left to the fiduciary to employ its own attorneys to investigate, defend or negotiate for the settlement of any claim provided they at all times cooperate to the fullest extent with the insurers' counsel and give consideration to any opinions expressed by them. All reasonable disbursements and fees of the fiduciary's attorneys incurred in connection with the claim should be considered a part of the loss with reference to which such fees or disbursements are incurred, and the total should be added to the amounts allowed the claimants in the adjudication or settlement, if any is made, subject of course to the deductible or first loss as expressed in the contract. In other words, the insurer's liability should be for the claim as a whole; and the claim as a whole should include whatever sum is actually paid in settlement and the reasonable costs and disbursements of the fiduciary incurred with the consent of the insurers in connection therewith. This means in the case of a "self-discovery" the 
amount actually paid in settlement of the particular act or acts self-discovered and made good with the consent of the insurers, and, in the case of a breach of trust for which the fiduciary is held accountable by some court, the amount which the fiduciary is directed to make good to the claimants as a class. This may mean the life-tenants as a class or it may mean the remaindermen as a class, depending upon whether the accounting is an intermediate accounting or a final accounting and whether the claimants are life-tenants or remaindermen. While it is obviously necessary to place a reasonable limit of time upon the discovery of losses in the event of cancellation or non-renewal of this type of insurance, there must be sufficient time allowed to permit the fiduciary to account to the courts and so bring about a legal review of its acts in the light of the circumstances existing at the time the action was taken. Three years should be ample for this purpose because within that time executors' accounts will have been reviewed in an executor's accounting and trustees' accounts will be subject to at least an intermediate accounting. If the insurance is renewed from year to year, or from one term of years to another, the protection should be fully continuous from the date of taking out the first contract and thereby permit recovery on claims made by remaindermen as well as by life-tenants.

\section{Who Shoutd Be INSUREd?}

Insurance of this sort is obviously for the protection of the fiduciary and/or its successors in business. It should only be available, however, to corporate fiduciaries of experience and reputation. This means that the personnel in direct charge of the trust accounts must themselves be equipped by education and training not only to inspire personal confidence and to perform their individual duties with sympathetic understanding of the problems of cestuis que trist, but also that they must be well informed with regard to the piffalls ahead of them and their employers through failure to use a proper record and check system on all of their fiduciary accounts and to maintain the degree of control of assets and of expenditures required in the performance of their trust. Most important of all they must know the limitations upon their authority with respect to the investment and reinvestment of the corpus and the rules as laid down with regard to allocation of gain or loss between principal and income. They must have competent legal advice in the shape of their own counsel standing either at their elbow or instantly available to support their own decisions in advance of their action or to advise them with respect to difficult legal situations. They must have the benefits of sound investment counsel either within their own organization or employed by them or by their trust estates individually. Above all else the institution itself must have length of service and sufficient resources to lend evidence of substantiality and to justify the confidence of the insurers in its management and personnel.

\section{Will. Insurance Encourage Careless Practices?}

One of the arguments against insurance of this kind is that it will encourage laxity on the part of the fiduciary. This, however, is not sound logic. It would be extremely unwise for any fiduciary because of the existence of insurance to relax in 
any way its careful attention to the details of trust department operation. This is so not only because of the necessary existence of a deductible clause and the aggregate limitations upon the liability assumed, but also because good faith requires the same observance of the rules of conduct with insurance as it does without insurance. This type of insurance can never cover a deliberate and conscious breach of trust, but must be limited to the failure of the human equation to function in the manner expected or, more particularly, against the uncertainties of the law and the possibilities of adverse decisions affecting circumstances adjudicated in the light of previous happenings which no reasonable man could possibly have anticipated.

\section{Reactions from the Public}

Insurance of this kind should not be used in any advertising or publicity, nor should it be referred to in any way by bank officers in their discussions with prospective clients of with beneficiaries of trusts. Its existence should not be known to the rank and file of the fiduciary's personnel. It is obviously not admissible evidence in court and cannot be used by the plaintiffs or their attorneys. In short, it should merely be used as banks customarily use their bankers' blanket bonds and forgery insurance, viz., as a means of recovery for losses actually sustained by way of claims asserted or by way of self-discovered acts for which honesty alone compels the fiduciary to make good without waiting for the claim to be asserted. "It should not react adversely upon clients or upon cestuis should its existence become known because in that case it should be referred to as a contract which prudently-managed banks require for the protection of both their stockholders and depositors against unreasonable demands and claims by dissatisfied or ill-advised cestuis. Its analogy to accountants' liability and physicians' and surgeons' liability insurance should invariably be pointed out to inquirers.

\section{Public Policy}

There can be no serious question about the right to insure against civil damage claims of any kind; least of all about the right to protect working capital against the unfortunate consequences of litigation, however lacking the grounds for complaint may be in the final analysis. It is impossible to prevent law suits in our country growing out of alleged breaches of trust in the conduct of fiduciary relationships because there are so many conflicting elements involved in the form of lifetenants, remaindermen, and special guardians and because access can be had to the courts with little or no expense and with absolutely no requirement with respect to the posting of security for costs-either court costs or costs of the opposing side. Our own courts are not nearly so strict as the English courts in regard to the posting of security for defendant's costs or so liberal with allowance of costs if successful, and accordingly insurance is needed as much to pay the costs of defense as to pay the amount allowed the claimants by way of damages for their loss. Dishonest and criminal acts should, of course, not be insured but with these exclusions there are no possible grounds for saying that insurance of this kind runs counter to public policy. 
